\title{
Hypofibrinogenaemia in metastatic carcinoma of the prostate: suppression of systemic fibrinolysis by heparin
}

\author{
P. W. STRAUB, G. RIEDLER, AND P. G. FRICK \\ From the Department of Medicine, Kantonsspital, University of Zürich, Switzerland
}

SYNOPSIS In a patient with generalized prostatic carcinoma and hypofibrinogenaemia heparin infusion on four occasions abolished systemic fibrinolysis as determined by euglobulin clot lysis time, bovine fibrin plate assay, thromboelastography, and immunoelectrophoretic demonstration of fibrinogen split products.

The pathogenesis of hypofibrinogenaemia in cases of prostatic carcinoma and the possibility of a direct heparin effect on fibrinolysis are discussed. Despite the lack of histological evidence for intravascular coagulation, the findings are considered additional evidence for the view that fibrinolysis in this syndrome may be secondary to intravascular coagulation.

In acquired hypofibrinogenaemia of malignant disease it is usually difficult to distinguish between the disappearance of fibrinogen by fibrinolysis and consumption of this protein by intravascular coagulation. The presence of thrombocytopenia, which may indicate the disappearance of platelets by a clotting process, is not a valid criterion for the differentiation of the two processes because hypofibrinogenaemia in malignant disease is very often associated with neoplastic bone marrow involvement. On the other hand, circulating fibrinolytic activity in the blood may not necessarily be the primary cause of hypofibrinogenaemia but may constitute the physiological consequence of intravascular coagulation. Anticoagulation is an elegant way for the differentiation since it corrects the hypofibrinogenaemia of intravascular coagulation (Merskey, Johnson, Pert, and Wohl, 1964). The following case report concerns a patient with metastatic carcinoma of the prostate in whom systemic fibrinolysis was repeatedly abolished by heparin treatment.

\section{MATERIALS AND METHODS}

Blood collection and routine laboratory assays for blood coagulation factors were performed according to the methods of Duckert (1958).

Fibrinogen was determined according to the method of Clauss (1957) and in some blood samples also according to that of Schulz (1955).

Received for publication 9 August 1966.
Thromboelastography was performed according to Hartert's method (1951), the assay being done on $0.25 \mathrm{ml}$. of oxalated plasma recalcified with $0.1 \mathrm{ml}$. of $1 / 10 \mathrm{M}$ calcium chloride.

For euglobulin lysis time determinations, fresh oxalated plasma was diluted with 15 volumes of distilled water and a $p H$ of 5.2 was obtained by gentle shaking in a $\mathrm{CO}_{2}$ atmosphere for three minutes. The precipitate was separated by centrifugation and redissolved in the original plasma volume of buffer. Of this solution, $0.5 \mathrm{ml}$. was clotted with $0.05 \mathrm{ml}$. of thrombin $(55 \mathrm{u} / \mathrm{ml}$.). The lysis time at $37^{\circ} \mathrm{C}$. was recorded.

The fibrin plate assay was performed according to the method of Astrup and Müllertz (1952).

Plasminogen was determined using the method of Alkjaersig, Fletcher, and Sherry (1959a), normal values ranging from 0.82 to 1.41 caseinolytic units.

Immunoelectrophoresis was performed with the method of Scheidegger (1955). Dilutions of the reagents were made with $0.9 \% \mathrm{NaCl}$ solution.

Anti-human-fibrinogen antibodies were prepared in rabbits according to Gitlin's method (Gitlin, Landing, and Whipple, 1953). The antiserum was absorbed with human serum. It gave no precipitation line when tested against various concentrations of normal human serum.

Plasma heparin was determined with a thrombin titration method (Brögli, 1965) ${ }^{1}$.

\section{CASE REPORT}

The 84-year-old patient F. W. (Jr. Nr. 1420/1965) had been receiving oestrogen treatment for a carcinoma of the prostate since 25 August 1964. He was admitted on ${ }^{1}$ Streptokinase Kabikinase was acquired from A/B Kabi, Stockholm, Sweden. 
14 May 1965, because haematomas had developed two days before. Physical examination showed haematomas of the right arm, the left elbow, and of the right abdominal wall, extending to the right hip. Gynecomastia was present. The prostate was the size of an apple, illconfined, without nodules. Laboratory data on admission are summarized in Tables I and II.

\section{TABLE I}

\section{ROUTINE LABORATORY DATA ON ADMISSION}

$\begin{array}{ll}\text { Haemoglobin } & 5 \cdot 7 \mathrm{~g} \text {. per } 100 \mathrm{ml} . \\ \text { Haematocrit } & 17 \% \\ \text { Erythrocytes } & 1.8 \mathrm{millions} \text { per } \mathrm{mm}^{3} \\ \text { Reticulocytes } & 3.4 \% \\ \text { Leucocytes } & 6,300 \text { per mm. } \\ \text { Platelets } & 91,000 \text { per mm. } \\ \text { Sternal marrow smear: tumour cell clusters, } & \text { no normal elements } \\ \text { Blood urea nitrogen } & 46 \mathrm{mg} \text {. per } 100 \mathrm{ml} . \\ \text { Electrolytes } & \text { Normal } \\ \text { Serum protein } & 7 \cdot 1 \mathrm{~g} \cdot \text { per } 100 \mathrm{ml} . \\ \text { Paper electrophoresis } & \text { Normal } \\ \text { Bilirubin } & 0.4 \mathrm{mg} . \text { per } 100 \mathrm{ml} . \\ \text { Calcium } & 9 \cdot 8 \mathrm{mg} \text {. per } 100 \mathrm{ml} . \\ \text { Inorganic phosphate } & 3.6 \mathrm{mg} \text {. per } 100 \mathrm{ml} . \\ \text { Calciuria } & 13.2 \mathrm{mg} \text {. per } 24 \text { hours } \\ \text { Alkaline phosphatase } & 1.6 \mathrm{u} . \\ \text { Acid phosphatase } & 45.6 \mathrm{u} . \\ \text { Transaminases } & \text { Normal }\end{array}$

TABLE II

DATA ON COAGULATION AND FIBRINOLYSIS ON ADMISSION

\begin{tabular}{|c|c|c|}
\hline & Patient & Normal \\
\hline Clotting time (Lee-White) (min.) & 30 & $7-10$ \\
\hline Recalcification time (sec.) & 115 & $50-120$ \\
\hline Thrombin time (sec.) & $19 \cdot 5$ & 14 \\
\hline Prothrombin complex (Quick) (\%) & 57 & $70-100$ \\
\hline Residual prothrombin in serum (\%) & 3 & $1-7$ \\
\hline Fibrinogen (method of Clauss) & & \\
\hline $\begin{array}{l}\text { (mg./100 ml.) } \\
\text { (method of Schulz) }\end{array}$ & 60 & $150-500$ \\
\hline (mg./100 ml.) & 60 & $150-500$ \\
\hline Factor II $(\%)$ & 100 & $70-100$ \\
\hline Factor V $(\%)$ & 86 & $50-100$ \\
\hline Factor VII complex (\%) & 100 & $70-100$ \\
\hline Factor VIII $(\%)$ & 90 & $50-150$ \\
\hline Factor IX $(\%)$ & 36 & $50-150$ \\
\hline Factor $\mathrm{X}(\%)$ & 56 & $70-100$ \\
\hline $\begin{array}{l}\text { Thromboelastography: decrease of ar } \\
22 \text { to } 9 \mathrm{~mm} \text {. }\end{array}$ & $\begin{array}{l}\text { de from } \\
\text { hours }\end{array}$ & \\
\hline Euglobulin lysis time ( $\mathrm{hr}$.) & 4 & 4 \\
\hline $\begin{array}{r}\text { Bovine fibrin plate (lysis zone of } 0.03 \\
\text { of plasma) (mm. }\end{array}$ & & \\
\hline Plasminogen (caseinolytic units) & 0 & $0.82-1 \cdot 41$ \\
\hline Fibrinogen split products in serum & Present & Absent \\
\hline
\end{tabular}

From 14 May to 17 May the patient received seven blood transfusions and new haematomas formed rapidly. On 17 May fibrinolysis was more marked and the first heparin treatment was started. The data on blood coagulation and fibrinolysis during the four episodes of heparin infusion are presented in Figure 1. Because of the insidious extension of the haematomas 25 blood transfusions were given in all. The bilirubin level increased to a maximum of $14 \mathrm{mg}$. per $100 \mathrm{ml}$. on 3 June, with a direct fraction of $2.8 \mathrm{mg}$. per $100 \mathrm{ml}$. Despite a second trial of oestrogens in high dosage, starting on 28 May, the patient deteriorated and died on 3 June 1965. Necropsy showed a carcinoma solidum simplex of the prostate with osteoplastic metastases in the bones, a few lung metastases, but no involvement of the liver. Foci of extramedullary blood formation were noted in the spleen and liver. Multiple haemorrhages were present in the subcutaneous tissues, mucosae, and various parenchymal organs. No thrombosis was found.

\section{RESULTS AND COMMENT}

Table II summarizes the data on blood coagulation. Hypofibrinogenaemia was demonstrated by the method of Clauss which measures the protein which is capable of clotting, and by the heat-precipitation method of Schulz. Systemic fibrinolysis was documented by the positive fibrin plate assay, the shortened euglobulin lysis time, and by the progressive decrease of amplitude in the thromboelastogram. The fibrinolytic activity as measured by euglobulin lysis time and the thromboelastogram might have been falsely accentuated by the low plasma fibrinogen level. This objection, however, is invalidated by the unequivocal results with the bovine fibrin plate system and by the demonstration of fibrinogen split products in serum and plasma. The formation of the latter by fibrinolysis in vitro is unlikely since the concentration and electrophoretic mobility appear to be approximately the same in the plasma and in the serum of a given blood sample, the first being frozen immediately after venepuncture, the latter being incubated at $37^{\circ} \mathrm{C}$. for six hours. However, this possibility cannot be excluded since no inhibitor of fibrinolysis was added to the blood.

Heparin treatment was started with a single intravenous dose of $50 \mathrm{mg}$. and maintained by continuous intravenous infusion of 200 to $300 \mathrm{mg}$. in 1 litre of $5 \%$ glucose per day. Therapy was considered to be adequate when the thrombin time exceeded 30 seconds. Heparin therapy led to the euglobulin lysis time promptly returning to normal, to the disappearance of the lytic activity of the patient's plasma on bovine fibrin plates, and to the abolition of the thromboelastographic pattern of fibrinolysis in all four therapeutic trials (Fig.1). The disappearance of the fibrinogen split products during the first three courses of therapy adds indirect evidence for the suppression of fibrinolysis (Fig. 2).

Unfortunately certain other indirect methods for the evaluation of the heparin effect could not be used in this case: the plasma fibrinogen level was influenced by multiple transfusions and bleeding. Since no fibrinolysis inhibitor was added to the blood, it might also have been influenced by a continued fibrinogenolysis in vitro. The level of the plasmin-susceptible clotting factors $\mathrm{V}$ and VIII

Heparin (Liquemin, Roche) in ampoules of $5 \mathrm{ml}$. containing 5,000 i.u. per ml. was acquired from F Hoffmann-La Roche, Basel, Switzerland 


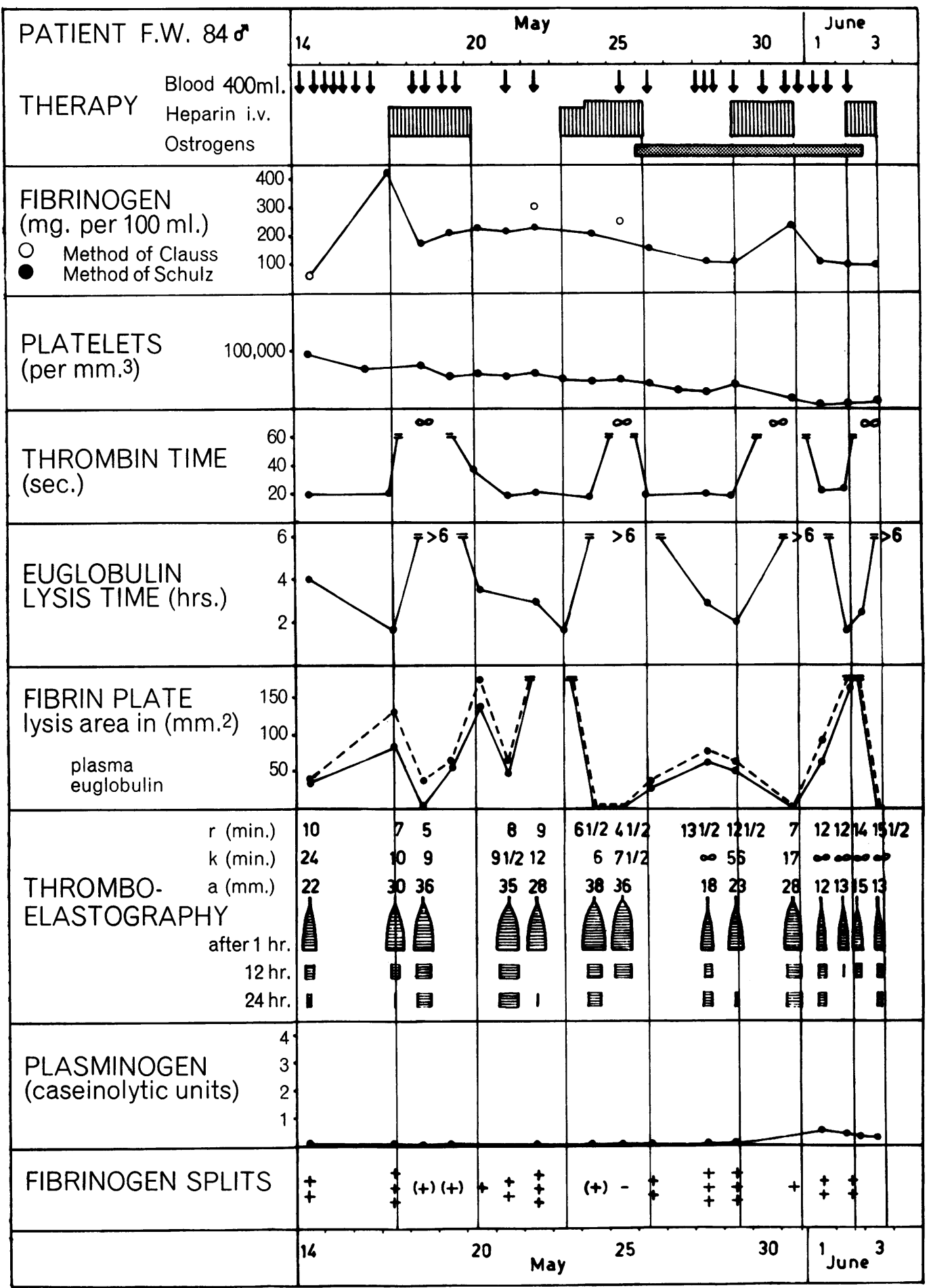

FIG. 1. Influence of heparin therapy on systemic fibrinolysis. 


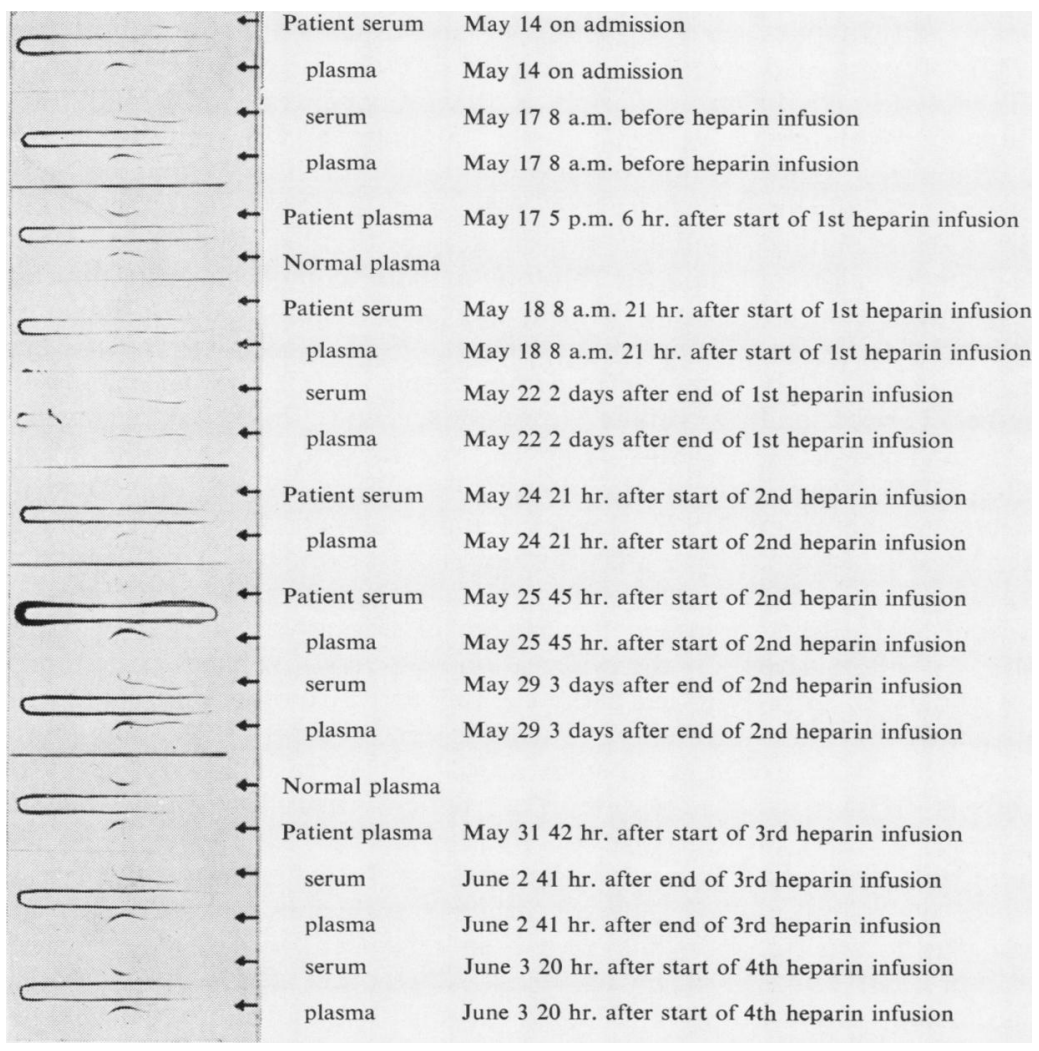

FIG. 2. Immunoelectrophoretic pattern of patient's plasma and serum during and between heparin infusions. Central well: rabbit anti-human fibrinogenantiserum. might also have been affected by transfusions and bleeding as well as by proteolysis in vitro. These determinations have therefore been omitted from Figure 1. Plasminogen was reduced to levels below the lower limit of accuracy of the method, where changes under therapy could not be followed. The thrombin time was not sufficiently prolonged to permit of the detection of the fibrinolysis-induced antithrombin VI. Moreover it was influenced by heparin treatment. In the presence of metastatic bone involvement the absence of an effect of anticoagulation on the platelet number is of no significance.

Results of experiments performed to test the possibility that heparin might have had a direct pharmaceutical effect on fibrinolysis are given in Table III. In a concentration of $25 \mu \mathrm{g}$. $/ \mathrm{ml}$. heparin did not inhibit the fibrinolytic effect of the patient's plasma of 17 May on the bovine fibrin plate, nor did an even higher concentration inhibit the lysis of the patient's euglobulin clot of the same blood sample. The plasma heparin levels attained during the first two courses of heparin treatment were $7 \cdot 4 \mu \mathrm{g} . / \mathrm{ml}$. on $18 \mathrm{May}$ and $4 \mu \mathrm{g} . / \mathrm{ml}$. on 31 May.

\section{DISCUSSION}

Acquired hypofibrinogenaemia in a case of prostatic carcinoma was first described in 1930 by Jürgens and Trautwein and was later observed by

TA BLE III

INFLUENCE OF HEPARIN in vitro ON FIBRINOLYSIS OF PATIENT PLASMA AND NORMAL PLASMA

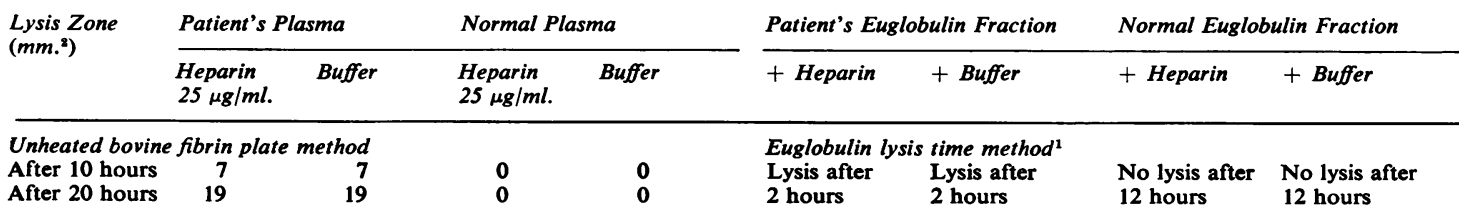

${ }^{1} 0.5 \mathrm{ml}$. euglobulin fraction $+0.1 \mathrm{ml}$. buffer or heparin $(250 \mu \mathrm{g} / \mathrm{ml}$. $)+0.1 \mathrm{ml}$. thrombin $(100 \mathrm{~N} . \mathrm{I} . \mathrm{H}$. units $/ \mathrm{ml}$.$) . Lysis time at 37^{\circ} \mathrm{C}$. 
others (Marder, Weiner, Schulman, and Shapiro, 1949; Cosgriff and Leifer, 1952). Tagnon has demonstrated the presence of fibrinolytic activity in the blood of such patients (Tagnon, Whitmore, and Schulman, 1952; Tagnon, Whitmore, Schulman, and Kravitz, 1953; Tagnon, Schulman, Whitmore, and Leone, 1953b). His evidence pointed to the presence of fibrinolytic activity also in the primary tumour and in the metastases of such tumours, whence it was thought to be released into the blood. This view has been widely accepted (Zeh and Ott, 1954; Soulier, Larrieu, and Wartelle, 1955; Cottier, Leupold, and Scheitlin, 1955; Crane, Ware, and Hamilton, 1955; Bergen and Schilling, 1958; Marchal, Duhamel, Lerousm Nivet, and Samama, 1959; Miller, Miesel, Jackson, and Collier, 1959; Stefan, Chrobak, Nerad, and Groh, 1959; Anderson and Bilsson, 1961; Bredt, 1962; Stocker and Maier, 1964). An alternative hypothesis, that of fibrinolysis secondary to intravascular coagulation, has been advanced.

EVIDENCE FOR A PRIMARY FIBRINOLYSIS Karhausen and Tagnon (1955) showed that tissue extracts of benign prostatic hypertrophy were able to digest casein directly in vitro and that the plasminogenrich euglobulin fraction of human plasma was not able to increase this process. Both observations favour Tagnon's concept of a proteolytic enzyme secreted by prostatic tumour tissue and a mechanism of fibrinolysis different from the normally observed activation of plasminogen to plasmin. In keeping with this theory are two published cases of prostatic carcinoma with fibrinolysis which had an increased level of plasminogen (Aboulker et al., 1955). However, Albrechtsen (1959) later demonstrated that prostatic gland extracts have a strong plasminogen activator activity. The observation of a patient whose fibrinolysis was not influenced by dicoumarol for two months treatment for venous thrombosis has been used as an argument against fibrinolysis secondary to intravascular coagulation (Sigstad and Lamvik, 1963). Moreover, certain published cases of the syndrome did not have thrombocytopenia (Aboulker et al., 1955; Bergen and Schilling, 1958; Andersson and Nilsson, 1961; Boros, Tarnoky, Vereczkey, and Rak, 1962; Miller et al., 1959; Stocker and Maier, 1964).

EVIDENCE FOR INTRAVASCULAR COAGULATION WITH SECONDARY FIBRINOLYSIS Although in the presence of bone involvement by prostatic carcinoma the frequently observed thrombocytopenia is not a valid argument for intravascular coagulation, a rapid drop of platelets from normal to 56,000 per $\mathrm{mm}^{3}$ within 10 hours, as observed in a patient of
Frick (1956), is not explained by bone marrow failure and has led to the postulate of intravascular coagulation as the primary cause of hypofibrinogenaemia. Seale, Jampolis, and Bargen (1951) had observed fibrin thrombi in liver, glomeruli, and endocrine organs of such a patient. Cases have been published presenting with fibrinolysis and simultaneous thrombo-embolic complications (Albrechtsen, 1959; Rapaport and Chapman, 1959; Samama, Marchal, and Klotz, 1965). Finally, fibrinolysis has not been demonstrable in all the patients with prostatic carcinoma and hypofibrinogenaemia (Seale, Jampolis, and Bargen, 1951; Crane, Ware, and Hamilton, 1955; Swan, Wood, and Daniell, 1957; Rapaport and Chapman, 1959). The assumption that fibrinolysis is secondary to intravascular coagulation implicates the activation of the physiological mechanism of fibrinolysis, and is favoured by the observation of a very low plasminogen level in our patient as well as in two other published cases. (Phillips, Skrodelis, and Furey, 1959). Moreover, the administration of seven transfusions after admission in our patient was followed by a marked increase of the fibrinolytic activity and of the haemorrhagic diathesis. In defibrination syndromes. of different origin transfusions or fibrinogen infusions have been shown to increase the haemorrhagic tendency (Albrechtsen, 1959; Stefan et al., 1959; Blix, 1961), possibly by substituting plasminogen. The well-known beneficial effect of epsilon amino-caproic acid on fibrinolysis in this syndrome appears to constitute another argument for the activation of plasminogen, since the drug primarily inhibits this reaction (Alkjaersig, Fletcher, and Sherry, 1959b). Moreover, Naeye (1962) reported a case of a patient with disseminated carcinoma of the prostate and afibrinogenaemia who developed widespread intravascular thrombosis while under treatment with epsilon-amino caproic acid, and postulated that the fibrinolysis inhibitor had unmasked an underlying process of intravascular coagulation. The repeated rapid suppression of fibrinolysis by heparin in the present patient favours the assumption of intravascular coagulation with secondary fibrinolysis. That no thrombosis was. found at necropsy may be explained by the removal of fibrin deposits by reactive fibrinolysis.

However, heparin itself may have an antifibrinolytic action. The literature on this subject is highly controversial (Halse, 1947; Astrup, Crookston, and McIntyre, 1950; Schidhauser-Kopp and Eichenberger, 1952; Schultze and Schwick, 1952; Astrup and Alkjaersig, 1952; Paly and Kline, 1954; Sandritter, Bergerhof, and Kroker, 1954; Giacomazzi, 1955; Greig, 1956; Buluk and Januszko, 1957; Hume, 1958; Von Kaulla and McDonald, 
1958; Lackner and Merskey, 1960; Blix, 1962; Konttinen, 1962; Berkarda, 1963; Bielawiec and Bilsson, 1964; Lewis, Kerber, and Wilson, 1964; Merskey, Johnson, Pert, and Whol, 1964; Nilsson, Bielawiec, and Bjorkman, 1964). Whereas some reports indicate an accelerating effect of heparin on fibrinolysis (Halse, 1947; Schultze and Schwick, 1952; Schmidhauser-Kopp and Eichenberger, 1952; Sandritter, Bergerhof, and Kroker, 1954; Giacomazzi, 1955; Greig, 1956; Buluk and Januszko, 1957; Lackner and Merskey, 1960), others have found no such effect (Nilsson, Bielawiec, and Björkman, 1964) and some favour a dose-dependent action (Von Kaulla and McDonald, 1958; Konttinen, 1962), or even a frank inhibition of fibrinolysis by heparin (Astrup, Crookston, and McIntyre, 1950; Astrup and Alkjaersig, 1952; Paly and Kline, 1954; Blix, 1962; Berkarda, 1963; Holemans et al., 1963; Nilsson et al., 1964; Bielawiec and Nilsson, 1964). The latter results in vitro even prompted the unsuccessful therapeutic use of heparin three days before death in a patient with prostatic carcinoma and fibrinolysis (Miller et al., 1959). Holemans and co-workers (1963) described the inhibition of activation of fibrinolysis in vitro by heparin concentrations of more than $100 \mu \mathrm{g}$. per ml. of plasma. These authors have calculated that inhibitions of fibrinolysis in vivo would have to be expected only with plasma concentrations of more than $30 \mu \mathrm{g}$. per $\mathrm{ml}$., which by far exceed the values observed in our patient. However, Nilsson et al. have pointed out that an inhibition of fibrinolysis activation in vivo should be expected with blood heparin concentrations of 1 to 2 units $/ \mathrm{ml}$. They found plasmin itself unaffected by heparin. This would explain our observation that heparin concentrations of more than three times those attained in vivo did not inhibit the fibrinolytic activity of our patient's plasma in vitro.

In view of the prompt abolition by heparin of a considerable systemic fibrinolysis in our patient we assume that the suppression of fibrinolysis by heparin was due to its anticoagulating rather than to a still very controversial direct pharmaceutical effect. The observations would then be additional evidence for the view that in metastatic carcinoma of the prostate the proteolytic state is secondary to intravascular coagulation.

\section{REFERENCES}

Aboulker, P., Soulier, J. P., Larrieu, M. J., and Wartelle, O. (1955). Presse méd., 63, 353.

Albrechtsen, O. K. (1959). Thesis, Copenhagen University. Acta physiol. scand., suppl., 165.

Alkjaersig, N., Fletcher, A. P., and Sherry, S. (1959a). J. clin. Invest. 38, 1086.

- 工, (1959b). J. biol. Chem., 234, 832.

Andersson, L., and Nilsson, I. M. (1961). Acta chir. scand., 121, 291.

Astrup, T., Crookston, J., and MacIntyre, A. (1950). Acta physiol. scand., 21, 238.
- and Alkjaersig, N. (1952). Nature (Lond), 169, 314.

and Müllertz, S. (1952). Arch. Biochem., 40, 346.

Bergen, S., Jr., and Schilling, F. J. (1958). Ann. intern. Med., 48, 389. Berkarda, B. (1963). Lancet, 1, 555.

Bielawiec, M., and Nilsson, I. M. (1964). Xth Congr. int. Soc. Haemat., Stockholm, (Abstr.), G:114.

Blix, S. (1961). Acta med. scand., 169, 71.

(1962). Ibid., suppl. 386.

Boros, M., Tarnoky, K., Vereczkey, C., and Rak, K. (1962). Z. klin. Med., 157, 68.

Bredt, J. (1962). Blut, 8, 22.

Brögli, H. (1965). Thrombos. Diathes. haemorrh. (Stuttg.), 13, 401.

Buluk, K., and Januszko, T. (1957). Pat. pol., 8, 107.

Clauss, A. (1957). Acta haemat. (Basel), 17, 237.

Cosgriff, S. W., and Leifer, E. (1952). J. Amer. med. Ass., 148, 462.

Cottier, P., Leupold, R., and Scheitlin, W. (1955). Schweiz. med. Wschr., 85, 781.

Crane, J. J., Ware, A. G., and Hamilton, J. (1955). J. Urol., 73, 379.

Duckert, F. (1958). In Rapports présentés au 3me Congrès International de Biologie Clinique. Bruxelles (1957), p. 635. Presses Académiques Europénenes, Brussels.

Frick, P. G. (1956). Acta haemat. (Basel), 16, 11.

Giacomazzi, G. (1955). Policlinico, Sez. med., 62, 226.

Gitlin, D. J., Landing, B. H., and Whipple A. (1953). J. exp. Med., 97, 163.

Greig, H. B. W. (1956). Lancet, 2, 16.

Halse, T. (1947). Klin. Wschr., 24-25, 728.

Hartert, H. (1951). Z. ges. exp. Med., 117, 189.

Holemans, R., Adamis, D., and Horace, J F. (1963). Thrombos. Diathes. haemorrh. (Stuttg.), 9, 446.

Hume, R. (1958). Brit. Heart J., 20, 15.

Jürgens, R., and Trautwein, H. (1930). Dtsch. Arch. klin. Med., 169, 28.

Karhausen, L., and Tagnon, H. J. (1955). Acta clin. belg., 10, 471.

Konttinen, Y. (1962). Scand. J. clin. Lab. Invest., 14, 15.

Lackner, H., and Merskey, C. (1960). Brit. J. Haemat., 6, 402.

Lewis, J. H., Kerber, C. W., and Wilson, J. H. (1964). Amer. J. Physiol., 207, 1044

Marchal, G., Duhamel, G., Leroux, M., Nivet, M., and Samama, M. (1959). Sang, 30, 472.

Marder, M., Weiner, M., Shulman, P., and Shapiro, S. (1949). N.Y. St. J. Med., 49, 1197.

Merskey, C., Johnson, A. J., Pert, J. H., and Wohl, H. (1964). Blood, 24, 701.

Miller, J. M., Meisel, H. J., Jackson, D. A., and Collier, C. S. (1959). J. Urol., 81, 672.

Naeye, R. L. (1962). Blood, 19, 694.

Nilsson, I. M. Bielawiec M., and Björkman, S. E. (1964). Scand. J. Haemat., 1, 75.

Paly, S. N., and Kline, D. L. (1954). Yale J. Biol. Med., 26, 486.

Phillips, L. L., Skrodelis, V., and Furey, C. A. (1959). Cancer (Philad.), $12,721$.

Prout, G. R., Siegel, M., Cliffton, E. E., and Whitmore, W. F., Jr. (1956). J. Amer. med. Ass., 160, 840.

Rapaport, S. I., and Chapman, C. G. (1959). Amer. J. Med., 27, 144.

Samama, M., Marchal, G., and Klotz, A. (1965). Xth Congr. Soc. europ. Haemat., Strasbourg, 54, (abstr.).

Sandritter, W., Bergerhof, H. D., and Kroker, R. (1954). Frankfurt. $Z$. Path., 65, 342.

Scheidegger, J. J. (1955). Int. Arch. Allergy, 7, 103.

Schmidhauser-Kopp, M., and Eichenberger, E. (1952). Experientia (Basel), 8, 354.

Schultze, H. E., and Schwick, G. (1952). Hoppe-Seylers Z. physiol. Chem., 289, 26.

Schulz, F. H. (1955). Ärztl. Lab., 1, 107.

Seale, R. A., Jampolis, R. W., and Bargen, J. A. (1951). Surg. Clin. N. Amer., 31, 1111

Sigstad, H., and Lamvik, J. (1963). Acta med. scand., 173, 215.

Stefan, H., Chrobak, L., Nerad, V., and Groh, J. (1959). Z. Urol., 52, 735.

Stocker, H., and Maier, C. (1964). Schweiz. med. Wschr., 94, 1373.

Swan, H. T., Wood, K. F., and Daniel, O. (1957). Brit. med. J., 1, 495.

Tagnon, H. J., Whitmore, W. F., Jr., and Shulman, N. R. (1952). Cancer (Philad.), 5, 9.

- - - - , and Kravitz, S. C. (1953a). Ibid., 6, 63.

, Schulman, P., Whitmore, W. F., Jr., and Leone, L. A. (1953b). Amer. J. Med., 15, 875.

Von Kaulla, K. N., and McDonald, T. S. (1958). Blood, 13, 811.

Zeh, E., and Ott, H. (1954). Acta haemat. (Basel), 12, 106. 